\title{
SUNDA WIWITAN BADUY: Agama Penjaga Alam Lindung di Desa Kanekes Banten
}

\author{
Masykur Wahid \\ IAIN "Sultan Maulana Hasanuddin” Banten \\ Telp.081510497542,email: masykurwahid@yahoo.com
}

Abstract

Baduy-style Islamic is pronounced with syahadat and practiced with tapa to maintain and preserve the natural heritage, karuhun. Tapa of Baduy is working in the fields to plant rice as a form to practice Islamic teachings, by mating the goddess of rice to the earth. Baduy's action was guided by the pikukuh, custom, following the buyut, taboo. Religious teachings, tapa, pikukuh and buyut have shaped simple personalities Baduy people in maintaining the Kanekes natural conservation. Thus, welfare and peace can be felt by mankind.

What are Sunda Wiwitan beliefs? How does Sunda Wiwitan practice their religious ritual? This paper attempts to answer the previous questions in religious studies that describe the system of religion and religious rituals Sunda Wiwitan. In the perspective of religion phenomenology issue, the phenomena are studied using direct observation method and in-depth interviews.

One of the finding illustrated that the Baduy people's faith and obedience to God appears in their actions in taking care of forests, rivers and mountain to life in harmony. Their faith is not in the form of memorizing or interpreting old religious scripture. Furthermore, worship rituals are practiced by working in the fields under custom rules guidance and abiding the taboo to have successful harvest and prosperous people. Worship is not intended to become a respected man or benefactor. This is the Sunda Wiwitan people with life perspective of maintaining the Kanekes natural conservation.

Key words: Baduy, Sunda Wiwitan, syncretism, religious rituals

Abstrak

Islam ala Baduy diucapkan dengan syahadat dan diamalkan dengan tapa untuk menjaga dan melestarikan alam warisan karuhun, nenek moyang. Tapa Baduy adalah bekerja di ladang dengan menanam padi sebagai amalan ajaran agama, mengawinkan dewi padi dengan bumi. Tindakan masyarakat Baduy itu berpedoman kepada pikukuh, aturan adat, dengan mematuhi buyut, tabu. Ajaran agama, tapa, pikukuh dan buyut telah mengkonstruksi pribadi-pribadi Baduy yang sederhana dalam menjaga alam lindung Kanekes. Sehingga, kesejahteraan dan kedamaian dapat dirasakan oleh umat manusia.

Bagaimana keyakinan masyarakat Sunda Wiwitan? Bagaimana praktik ibadah ritual agama Sunda Wiwitan? Tulisan ini menjawab pertanyaan itu di dalam studi religi yang memaparkan sistem religi dan ritual keagamaan Sunda Wiwitan. Dalam perspektif fenomenologi agama permasalahan itu dikaji dengan metode observasi terlibat langsung dan wawancara mendalam.

Ditemukan jawaban bahwa keimanan dan ketaatan umat Baduy kepada Allah tampak dalam tindakan mereka menjaga hutan, sungai dan gunung hidup harmoni. Keimanannya bukan dalam hafalan ataupun penafsiran kitab suci. Sedangkan, 
ibadah ritualnya dipraktikkan lewat bekerja di ladang dengan aturan adat dan patuh pada tabu supaya panen berhasil dan umat sejahtera. Ibadahnya bukan ingin menjadi manusia yang dihormati ataupun dermawan. Inilah umat Sunda Wiwitan dengan pandangan hidup menjaga alam lindung Kanekes.

Kata kunci: Baduy, Sunda Wiwitan, sinkretisme, ritual agama

\section{Pendahuluan}

Salah satu warisan keyakinan masyarakat Indonesia, agama Sunda Wiwitan, tetap hidup lestari dan damai di tengah-tengah hutan tua lebat, hulu sungai dan puncak gunung Kendeng Banten Selatan. Sunda Wiwitan adalah agama masyarakat Baduy yang menghormati roh karuhun, nenek moyang (Permana, 2006: 37). Wiwitan berarti jati, asal, pokok, pemula, pertama. Sunda Wiwitan dalam Carita Parahiyangan disebut kepercayaan Jati Sunda. Naseni, seorang kokolot Kampung Cikeusik, menjelaskan bahwa "kepercayaan animisme masyarakat Baduy telah dimasuki unsur-unsur agama Hindu dan agama Islam". Pada tahun 1907, menurut laporan Controller Afdeeling, di wilayah Lebak terdapat komunitas masyarakat beragama Hindu sebanyak 40 keluarga (Ekadjati, 1995: 72). Sedangkan, Islam pertama dikenal oleh masyarakat Baduy di Kampung Cicakal Girang sejak kurang lebih 300 tahun silam. Kira-kira tahun 1680-an Islam dianut oleh masyarakat Baduy di Kampung Cikakal Girang.

Sebagian antropolog menganggap bahwa sinkretisisme sebagai salah satu dari tiga hasil proses akulturasi: penerimaan, penyesuaian dan reaksi. Dalam Antropology Today: An Encyclopedia (1953) R. Beals menjelaskan bahwa "acculturation is combining original and foreign traits either in harmonious whole or with retention of conflicting attitudes which are reconciled in everyday behavior according to specific occasions." Jelasnya, sinkretisasi adalah proses penggabungan dan pengombinasian unsur-unsur asli dengan unsur-unsur asing yang dapat memunculkan sebuah pola budaya baru (Ahimsa-Putra, 2006: 338).

Tulisan ini membahas religi umat Sunda Wiwitan. Ada dua pertanyaan yang ingin dijawab. Bagaimana keyakinan masyarakat Sunda Wiwitan? Bagaimana praktik ibadah agama Sunda Wiwitan? Secara teoritis konsep agama dapat dipahami dengan membedakannya dari konsep magic. Menurut James Frazer, secara substansial agama menekankan dimensi ekspresif, sedangkan magic menekankan dimensi instrumental dari kehidupan. Dimensi ekspresif merupakan ruang untuk menyatakan dan menyimbolkan relasi-relasi sosial dan kosmologis tertentu. Sedang dimensi instrumental merupakan ruang untuk mencapai tujuan-tujuan khusus. Tidak hanya itu, agama juga mengarahkan diri pada relasi aku-Engkau, dari pertemuan personal dalam mengabdi dan memuji Tuhan 
atau dewa sejauh ia sendiri akan dilayani oleh-Nya. Sedangkan, magic dalam bentuk murni menetapkan relasi aku-Dia yang manipulatif dengan alam (Martin Buber dalam Dhavamony, 1995: 51). Konsep budaya yang digunakan mengikuti pemikiran Geertz, bahwa budaya adalah "suatu pola makna-makna yang diteruskan secara historis yang terwujud dalam simbol-simbol (Geertz, 1973: 89). Sistem konsep-konsep yang diwariskan yang terungkap dalam bentuk-bentuk simbolis menjadikan manusia dapat berkomunikasi, melestarikan, dan mengembangkan pengetahuannya tentang kehidupan dan sikap-sikap terhadap kehidupan". Konsep budaya ini berkaitan dengan pandangan dunia (world view) masyarakat Baduy. Lebih lanjut, pandangan dunia dijelaskan sebagai "gambaran mengenai kenyataan apa adanya, konsep mengenai alam, diri dan masyarakat" (Geertz, 1973: 127).

Tulisan ini didasarkan pada hasil kajian terhadap masyarakat yang tinggal di Desa Kanekes, Kecamatan Leuidamar, Kabupaten Lebak, Propinsi Banten. Dalam kajian ini, fenomenologi agama digunakan untuk menyelidiki sejarah agama dan budaya Baduy secara sistematis melalui pengklasifikasian dan pengelompokan data-data yang tersebar luas dengan cara tertentu agar ditemukan pandangan komprehensif mengenai isi dan makna religius yang terkandung di dalam agama dan budaya masyarakat Baduy (Dhavamony, 1995:25-26). Selain itu, penulis terlibat langsung secara cermat untuk mengamati dan memahami fenomena sistem religi dan ritual keagamaan Baduy yang terjadi baik di wilayah Desa Kanekes maupun wilayah sekitarnya. Keterlibatan langsung dalam ruang etnografi digunakan untuk menetapkan calon informan (Spradley, 2006: 72). Pada akhirnya wawancara mendalam terhadap informan dilakukan untuk menguatkan data-data lama dan menemukan data-data baru. Di samping itu, digunakan metode triangulasi untuk proses pemeriksaan dan pengujian data-data yang diperoleh hingga tahap analisis dilakukan (Miles, 1992: 437).

\section{Geografi dan Demografi Baduy}

Masyarakat Baduy bertempat tinggal di tanah adat (ulayat) di daerah pedesaan di antara perbukitan dan pegunungan Kendeng, Banten Selatan. Yakni, Desa Kanekes, Kecamatan Leuwidamar, Kabupaten Lebak, Propinsi Banten. Letak Desa Kanekes sekitar 17 kilometer sebelah selatan kota Kecamatan Leuwidamar. Sekitar 38 kilometer sebelah selatan kota Kabupaten Lebak. Sekitar 65 kilometer sebelah selatan Ibukota Propinsi Banten. Dan, sekitar 172 kilometer sebelah barat Ibukota Jakarta. Berdasarkan Peraturan Daerah Kabupaten Lebak No. 32 Tahun 2001, luas desa ini kira-kira 5.101,85 hektar. 
Luasnya terdiri dari pemukiman masyarakat seluas 2.101,85 hektar dan hutan lindung mutlak (taneuh larangan) seluas 3.000 hektar. Luasnya di antara desa-desa di wilayah Propinsi Banten, Desa Kanekes adalah wilayah pedesaan yang terluas.

Penduduk masyarakat Baduy berjumlah 10.879 jiwa, laki-laki 5.465 jiwa dan perempuan 5.414, berdasarkan Data Sensus Penduduk Desa Kanekes tanggal 28 Pebruari 2008. Dilihat dari tahun-tahun sebelumnya, pertumbuhan penduduk sangat pesat sebesar $1.79 \%$ per tahun. Seiring pertumbuhan warga yang pesat, perubahan lahan tempat tinggal (teritorial) pun terus menerus berkembang meluas. Dalam Peraturan Daerah No. 23 Tahun 2001 berdasarkan posisi, dalam dan luar, tempat tinggal warga, secara administratif masyarakat Baduy dibagi menjadi dua: Baduy Dalam dan Baduy Luar. Masyarakat Baduy Dalam yang berjumlah 1.053 jiwa menempati tanah yang didiami tiga kampung: Cikeusik, Cikertawa dan Cibeo. Masyarakat Baduy Luar yang berjumlah 9.826 jiwa menempati tanah yang didiami 57 kampung dan 5 babakan (pemekaran kampung). Pada tahun sebelumnya, 2003 diketahui bahwa masyarakat Baduy Luar hanya memiliki 45 kampung dan 6 babakan.

\section{Asal Usul Baduy}

Baduy merupakan sebutan populer orang lain terhadap masyarakat Desa Kanekes Banten. Sebutan Baduy muncul sesudah agama Islam masuk ke daerah Banten utara pada abad ke-16, sekitar tahun 1522-1526 (Garna, 1987: 36). Akan tetapi, orang Baduy juga memiliki ciri sebagai berikut (Garna, 1987: 16-17) :

"Kesetiaan orang Baduy kepada agama yang diwarisi secara turun temurun dari nenek moyangnya seperti keadaan sebelum Hindu dan Islam berkembang di Jawa Barat serta letak desanya yang tak mudah dicapai orang seolah-olah memperkuat angggapan bahwa orang Baduy itu bukan orang Sunda”.

Meskipun demikian, pada tahun 1822 C.L. Blume pernah menulis bahwa masyarakat Baduy berasal dari Kerajaan Sunda Kuno, yakni Pajajaran, yang bersembunyi ketika kerajaan Pajajaran runtuh pada awal abad ke-17, dan sejalan pesatnya kemajuan kerajaan Banten Islam (Garna, 1993b: 144; Permana, 2006: 26). Terlepas dari perdebatan para ahli sejarah tentang sebuatan Baduy, penelusurannya dapat diteruskan dan ditemukan di banyak sumber.

Sedangkan menurut Saleh Danasasmita dan Anis Djatisunda, Baduy adalah masyarakat setempat yang dijadikan mandala (kawasan suci) secara resmi oleh raja, sebab masyarakatnya berkewajiban memelihara kabuyutan, tempat pe-muja-an nenek 
moyang, bukan Hindu atau Budha. Kabuyutan di Desa Kanekes dikenal dengan kabuyutan Jati Sunda atau Sunda Wiwitan. Dari sinilah, masyarakat Baduy sendiri menyebut agamanya adalah Sunda Wiwitan, Sunda Pertama (Sam, 1986: 4-5; Permana, 2006: 27). Hal itu menjelaskan juga bahwa asal usul Baduy secara tepat bisa ditemukan di dalam diri masyarakat Baduy sendiri yang kukuh melestarikan alam lindung pegunungan Kendeng sebelum ekspedisi Islam datang mengubah kepercayaan mereka.

\section{Batara Tunggal, Ciptaan Tuhan}

Tuhan yang diyakini oleh umat Sunda Wiwitan adalah Allah, sebagaimana terucapkan di dalam kalimat syahadat Baduy (Sam dkk., 1986: 62). Meskipun, mereka menyebut-Nya Batara Tunggal (Tuhan Yang Maha Esa), Batara Jagat (Penguasa Alam) dan Batara Seda Niskala (Yang Gaib). Mereka mempercayai Sang Hiyang Keresa (Yang Maha Kuasa) atau Nu Ngersakeun (Yang Menghendaki) sebagai pemegang kekuasaan tertinggi. Tuhan Sunda Wiwitan bersemayam di Buana Nyungcung (Dunia Atas). Bahkan, diyakini bahwa semua dewa agama Hindu (Brahma, Wisnu, Siwa, Indra, Yama, dan lainlainnya) tunduk terhadap Batara Seda Niskala (Ekadjati, 1995: 73). Mereka beriman kepada yang gaib, yang tidak bisa dilihat dengan mata, tetapi dapat diraba dengan hati. Nabi-nabi yang diimani secara eksplisit adalah Nabi Adam dan Nabi Muhammad. Mereka beriman kepada hidup, sakit, mati dan nasib adalah titipan. Umat Sunda Wiwitan menjalankan juga ritual ibadah sunah Rasul, yakni sunat atau khitan (Djoewisno, 1987: 28). Ritus sunat diyakini sebagai nyelamkeun, mengislamkan, bagi laki-laki pada umur 47 tahun dan perempuan. Dan, mereka tak lupa melaksanakan ritual ibadah puasa kawalu, lebaran. Puasa ini dilakukan hanya sehari pada bulan pertama, kedua dan ketiga dalam setahun sekali (Sam dkk., 1986: 64).

Pengucapan nama Allah termaktub di dalam dua macam kalimat syahadat Baduy: Syahadat Baduy Dalam dan syahadat Baduy Luar. Pertama, kalimat syahadat Baduy Dalam, sebagai berikut:

Naskah Asli

"asyhadu syahadat Sunda jaman Allah ngan sorangan kaduanana Gusti Rosul ka tilu Nabi Muhammad ka opat umat Muhammad nu cicing di bumi angaricing nu calik di alam keueung". ngacacang di alam mokaha
Naskah Terjemahan asyhadu syahadat Sunda Allah hanya satu kedua para Rasul ketiga Nabi Muhammad keempat umat Muhammad yang tinggal di dunia ramai yang duduk di alam takut menjelajah di alam nafsu 
Kedua, kalimat syahadat Baduy Luar, berikut ini:

Naskah Asli

"asyhadu Alla ilaha illalah

wa asyhadu anna Muhammad da

Rasulullah

isun netepkeun ku ati

yen taya deui Allah di dunya ieu

iwal ti Pangeran Gusti Allah

jeung taya deui iwal ti Nabi

Muhammad utusan Allah".
Naskah Terjemahan

Asyhadu Alla ilaha illalah

wa asyhadu anna Muhammad da

Rasulullah

aku menetapkan dalam hati

bahwa tiada lagi Tuhan di dunia ini

selain Pangeran Gusti Allah

dan tiada lagi selain Nabi Muhammad utusan Allah)

Syahadat Baduy Dalam adalah syahadat Sunda Wiwitan yang disampaikan kepada puun, sebagaimana masa Islam awal syahadat Islam disampaikan kepada Nabi Muhammad. Sedangkan, syahadat Baduy Luar adalah syahadat Islam yang diucapkan ketika melangsungkan pernikahan secara Islami. Dikatakan oleh umat Sunda Wiwitan bahwa "kami mah ngan kabagean syahadatna wungkul, hente kabagean sholat". Bahwa mereka hanya memperoleh syahadatnya saja, sedangkan rukun-rukun Islam lainnya tidak pernah diperoleh (Sam dkk., 1986: 62-63).

Kekuasaan Tuhan dipahami oleh umat Sunda Wiwitan sebagai pencipta alam semesta. Dalam mitos penciptaan Baduy dijelaskan bahwa "dunia pada waktu diciptakan masih kosong, kemudian Tuhan mengambil segenggam tanah dari bumi dan diciptakanlah Adam. Dari tulang rusuk Adam terciptalah Hawa. Tuhan juga menciptakan Batara Tujuh, yaitu: (1) Batara Tunggal, (2) Batara Ratu, (3) puun yang dititipkan di Kanekes (Cikeusik, Cikertawana, Cibeo), (4) Dalem, (5) Menak, (6) Putri Galuh dan (7) Nabi Muhammad yang diturunkan di Mekah. Batara Tujuh merupakan Sanghyang Tujuh yang bersemayam di Sasaka Domasi" (Sam, 1986: 64). Dari mitos penciptaan ini, masyarakat Baduy menyakini bahwa manusia yang pertama kali diciptakan di bumi ini berada di Kanekes sebagai inti jagat, pancer bumi. Karena itu, mereka melaksanakan ritual ibadah pe-muja-an di Sasaka Domas sebagai penghormatan kepada roh karuhun, nenek moyang. Mereka menyakini juga agamanya adalah Sunda Wiwitan, bukan Hindu ataupun Islam. 
Nabi Adam diyakini oleh umat Sunda Wiwitan sebagai simbol penciptaan manusia pertama yang berada di Sasaka Domas. Keyakinan seperti ini terdapat juga di dalam agama masyarakat Jawa yang masih menghormati raja-raja, nenek moyang, mereka. Antara Nabi Islam, Batara Hindu dan raja Jawa terdapat relasi genealogis, seperti termaktub di dalam pembukaan kitab Babad Tanah Jawi, berikut ini (Ahimsa-Putra, 2006: 345):

"Sejarah raja-raja Jawa berawal dari Nabi Adam sebagai sumbernya. Nabi Adam menurut asal-usul menurunkan Nabi Sis. Nabi Sis sendiri kemudian berputra Nurcahya. Nurcahya menurunkan Nurasa. Dari Nurasa lahir putranya yang bernama Sang Hyang Wening kemudian menurunkan Sang Hyang Tunggal. Kemudian Sang Hyang Tunggal berputrakan sang Batara Guru. Batara Guru berputra lima, diberi nama: Batara Sambo, Batara Brama, Batara Maha Dhewa, Batara Wisnu, dan Dewi Sri. Batara Wisnu, putra keempat dari Batara Guru, bertakhta di suatu kerajaan di pulau Jawa, bergelar prabu Set. Istana Batara Guru itu yang disebut Suralaya, tempat tinggal para dewa (Sudibjo, t.t: 7).”

Dapat dipahami bahwa Batara Tunggal yang dipercayai oleh umat Sunda Wiwitan adalah manusia biasa yang tidak pernah mati, akan tetapi jasad dan rohnya ngahiyang, sirna, dari dunia ini. Mereka menyakini juga bahwa Batara Tunggal-lah yang mengatur nasib dan kehidupan manusia di muka bumi ini. Begitu pun, Dalem dan Menak adalah karuhun, nenek moyang yang jasad dan rohnya ngahiyang, sirna. Sebab itu, diyakini bahwa Kanekes tidak akan hilang hingga saat ini, seiring terpeliharanya keturunan puun (Sam dkk., 1986: 62-63). Secara formal-normatif, puun adalah pimpinan adat istiadat masyarakat Baduy. Untuk memimpin adat istiadat aspek spiritual puun dibantu oleh perangkat puun. Yaitu, baresan (dewan penasehat), tangkesan (peramal) dan girang seurat (pembantu pelaksana ritual). Selain puun diyakini sebagai pemimpin tertinggi adat, juga merupakan keturunan karuhun, nenek moyang, yang langsung mempresentasikannya di dunia. Selain menyakini adanya karuhun, masyarakat Baduy juga menyakini adanya guriang, sanghyang dan wangatua. Guriang dan sanghyang adalah penjelmaan para karuhun untuk melindungi keturunannya dari segala bahaya, baik dari gangguan orang jahat maupun makhluk-makhluk halus yang jahat. Sedangkan, wangatua adalah penjelmaan roh ibu dan bapak yang telah meninggal dunia. Para puun adalah orang-orang yang bertanggung jawab dan bertugas melestarikan kepercayaan warisan nenek moyang, pikukuh, supaya tidak terkena pengaruh proses perubahan sosial budaya dari luar (Permana, 2006: 40).

\section{Sasaka Domas, Kiblat Suci Baduy}


Kiblat ibadah pe-muja-an umat Sunda Wiwitan disebut Sasaka Domas, atau Sasaka Pusaka Buana atau Sasaka Pada Ageung. Sasaka Domas adalah bangunan punden berunduk atau berteras-teras sebanyak tujuh tingkatan. Setiap teras diberi hambaro, benteng, yang terdiri atas susunan "menhir" (batu tegak) dari batu kali. Pada teras tingkat keempat terdapat menhir yang besar dan berukuran tinggi sekitar $2 \mathrm{~m}$. Pada tingkat teratas terdapat "batu lumpang" dengan lubang bergaris tengah sekitar $90 \mathrm{~cm}$, menhir dan "arca batu". Arca batu ini disebut Arca Domas. Domas berarti keramat, suci. Tingkatan teras, makin ke selatan undak-undakan makin tinggi dan suci. Digambarkan oleh Koorders (1869), Jacob dan Meijcr (1891) dan Pleyte (1909) bahwa letaknya di tengah hutan tua yang sangat lebat, hulu sungai Ciujung dan puncak gunung Pamuntuan. Bangunan tua ini merupakan sisa peninggalan megalitik. Sebagai kiblat ibadah, Sasaka Domas diyakini sebagai tanah atau tempat suci, keramat (sacral), para nenek moyang berkumpul (Permana, 2006: 38 dan 89-90).

Di tanah suci ini umat Sunda Wiwitan melaksanakan ritual pe-muja-an. Ritus muja adalah ziarah memanjatkan doa dan membersihkan obyek utama pemujaan Baduy. Ibadah ritual pe-muja-an di Sasaka Domas dipimpin oleh puun Cikeusik. Tujuan ritus muja adalah untuk me-muja para karuhun, nenek moyang, dan menyucikan pusat dunia. Dalam ritual ini hanya orang-orang tertentu yang melaksanakan muja atas nama masyarakat Baduy secara keseluruhan. Yakni, para puun dan orang-orang yang ditunjuk. Orang-orang ditunjuk melaksanakan ritus mиja bukan didasarkan kriteria tertentu. Ritual ini dilaksanakan selama tiga hari: tanggal 16, 17 dan 18 pada bulan Kalima. Waktu tiga hari ritual terbagi terdiri dari, dua hari untuk pergi dan pulang, dan sehari untuk ibadah ritual muja (Permana, 2006: 88).

Prosesi ziarah menuju ke Sasaka Domas harus melalui sisi sebelah utara, tidak boleh dari sisi selatan. Ritual muja dimulai oleh puиn pada teras tingkat pertama, dengan menghadap ke selatan, arah puncak. Selesai ritual muja biasanya pada tengah hari, sekitar pukul 11.00-13.00. Setelah ritual muja, dilanjutkan dengan membersihkan dan membenahi pelataran teras. Sampai pada teras teratas (ketujuh), para pe-muja menyucikan muka, tangan dan kaki pada batu lumpang yang disebut Sanghyang Pangumbaran. Keadaan air di dalam "batu lumpang” adalah simbol keadaan alam Baduy. Jika airnya penuh dan jernih, menandakan akan turun hujan banyak, cuaca baik dan panen berhasil. Sebaliknya, jika air dangkal dan keruh menandakan kekeringan dan kegagalan panen. Pada keadaan "menhir" di puncak, jika dipenuhi lumut menandakan akan 
mendapatkan kesentosaan dan kesejahteraan dalam tahun bersangkutam, tetapi sebaliknya dapat memperoleh kesengsaraan dan kesulitan (Permana, 2006: 90-91).

Umat Sunda Wiwitan yang berniat, tidak diwajibkan, meminta berkah datang pada sore tanggal 18 Kalima dan menanti para pe-muja di alun-alun depan rumah jaro Cikeusik atas nama dan restu puиn Cikeusik. Mereka membentuk kelompok berdasarkan asal kampungnya. Setiap kelompok beranggota 5-10 orang dan memiliki juru bahasa dari kokolot kampung. Juru bahasa berfungsi mengantar, mengenalkan dan mengutarakan niat kedatangannya. Mereka wajib berpuasa dan mengenakan pakaian yang baik dan bersih. Masing-masing orang membawa sesajen dan uang kertas (semampunya) yang akan diserahkan kepada jaro sebagai imbalan berkah. Berbuka puasanya tergantung pada kedatangan para pe-тиja dan setelah selesai mandi serta isyarat dari puun Cikeusik. Waktu berbuka puasa biasanya antara pukul 15.00-19.00, waktu lingsir dan burit. Berbuka puasanya dengan luluy yang disediakan oleh palawari. Luluy adalah sejenis lemang atau lontong dari beras yang dibungkus daun patat dan dimasukkan dan dimasak di dalam bambu. Palawari adalah 5-7 orang laki-laki yang bertugas dan bertanggung jawab membuat luluy. Tujuan meminta berkah adalah memohon keselamatan dan kemurahan rejeki (Permana, 2006: 91-92).

Prosesi meminta berkah di rumah jaro Cikeusik. Seluruh kelompok duduk bersila di ruang tepas, sedangkan jaro duduk bersila di ruang imah. Juru bahasa lebih dahulu masuk ke ruang imah menghadap jaro untuk mengenalkan diri dan kelompoknya serta menyampaikan niat dan tujuan mereka. Jaro duduk bersila di sisi selatan ruang imah menghadap utara, sedangkan juru bahasa berada di sisi utara menghadap ke selatan (jaro). Juru bahasa langsung menyerahkan sesajinya kepada jaro. Setelah menerima sesaji, jaro mengambil sepotong luluy yang di dalamnya dimasukkan jukut komala dan lemah bodas. Jukut komala, rumput permata adalah lumut yang menempel di teras tingkat kedua Sasaka Domas, sedang lemah bodas, tanah putih. Keduanya diambil pada teras tingkat kedua dari sebelah utara. Lalu, luluy diberi jampi-jampi, ditiup tiga kali dan disuapkan kepada seorang peminta berkah. Akhirnya, juru bahasa memohon diri dan keluar meninggalkan ruang imah, lalu mempersilakan anggota kelompoknya masuk ke ruang imah secara bergiliran menghadap jaro. Mereka yang sudah mendapatkan berkah segera ke luar rumah jaro. Prosesi ini berlangsung hingga larut malam, bahkan pernah terjai hingga fajar (Permana, 2006: 92).

Prosesi meminta berkah berkiblat kepada prosesi ziarah ke Sasaka Domas. Yakni, berkiblat menghadap ke arah selatan, tempat suci, Sasaka Domas. Karena itu, kiblat 
ibadah pe-muja-an umat Sunda Wiwitan ke arah selatan. Hal ini berbeda dengan ibadah shalat umat Islam Indonesia yang berkiblat menghadap ke arah barat, Kabah. Meski demikian, pada dasarnya prosesi ibadah pe-muja-an di tanah suci, Sasaka Domas mirip dengan prosesi ibadah haji di tanah suci, Kabah. Ibadah haji dilaksanakan pada tanggal 8, 9 dan 10 Dzulhijah. Pada tanggal 9 Dzulhijah umat Islam yang tidak melaksanakan ibadah haji disunatkan berpuasa 'Arafah. Dan, sebagian umat Islam Indonesia berbuka puasa biasanya dengan nasi lontong atau ketupat. Setelah jamaah haji datang di rumah masing-masing, tidak sedikit masyarakat Islam yang datang dan meminta berkah kepada orang yang telah melaksanakan ibadah haji. Karena itu, yang jelas membedakan dengan Islam, keimanan dan ketaatan Sunda Wiwitan kepada Tuhan terkandung di dalam makna simboliknya supaya senantiasa menjaga dan melestarikan hutan, sungai dan puncak gunung berada dalam ekosistemnya supaya memberikan kedamaian dan kesejahteraan pada umat manusia.

\section{Pikukuh, Aturan Adat Mutlak}

Pandangan hidup (world view) umat Sunda Wiwitan berpedoman pada pikukuh, aturan adat mutlak. Pikukuh adalah aturan dan cara bagaimana seharusnya (wajibnya) melakukan perjalanan hidup sesuai amanat karuhun, nenek moyang. Pikukuh ini merupakan orientasi, konsep-konsep dan aktifitas-aktifitas religi masyarakat Baduy. Hingga kini pikukuh Baduy tidak mengalami perubahan apa pun, sebagaimana yang termaktub di dalam buyut (pantangan, tabu) titipan nenek moyang. Buyut adalah segala sesuatu yang melanggar pikukuh. Buyut tidak terkodifikasi dalam bentuk teks, tetapi menjelma dalam tindakan sehari-hari masyarakat Baduy dalam berinteraksi dengan sesamanya, alam lingkungannya dan Tuhannya. Buyut tentang tindakan masyarakat Baduy, sebagai berikut (Garna, 1988a: 53-54, 1993: 139; Permana, 1995: 38-39; Sam dkk., 1986: 47-48):

Naskah Asli

"buyut nu dititipkeun ka puun nagara satelung puluh telu bangsawan sawidak lima pancer salawe nagara gugung teu meunang dilebur lebak teu meunang diruksak larangan teu meunang ditempak buyut teu meunang dirobah lojor teu meunang dipotong pondok teu meunang disambung
Naskah Terjemahan (buyut yang dititipkan kepada puun negara tiga puluh tiga sungai enam puluh lima pusat dua puluh lima Negara gunung tak boleh dihancur lembah tak boleh dirusak larangan tak boleh dilanggar buyut tak boleh diubah panjang tak boleh dipotong pendek tak boleh disambung 
nu lain kudu dilainkeun nu ulah kudu diulahken nu enya kudu dienyakeun mipit kudu amit ngala kudu menta ngeduk cikur kudu mihatur

nyokel jahe kudu micarek ngagedag kudu beware

nyaur kudu diukur nyabda kudu diunggang

ulah ngomong sageto-geto ulah lemek sadaek-daek ulah maling papanjingan ulah jinah papacangan kudu ngadek sacekna nilas saplasna

Akibatna matak burung jadi ratu matak edan jadi menak matak pupul pengaruh matak hambar komara matak teu mahi juritan matak teu jaya perang matak eleh jajaten matak eleh kasakten" yang bukan harus ditiadakan yang lain harus dipandang lain yang benar harus dibenarkan mengambil harus pamit mengambil harus minta mengambil kencur harus memberitahukan yang punya mencungkil jahe harus memberi tahu mengguncang pohon supaya buahnya berjatuhan harus memberitahu terlebih dulu bertutur harus diukur berkata harus dipikirkan supaya tidak menyakitkan jangan bicara sembarangan jangan bicara seenaknya jangan mencuri walaupun kekurangan jangan berjinah dan berpacaran harus menetak setepatnya menebas setebasnya

Akibatnya bisa gagal menjadi pemimpin bisa gila menjadi menak bisa hilang pengaruh bisa hilang kewibawaan bisa kalah berkelahi bisa kalah berperang bisa hilang keberanian bisa hilang kesaktian)

Selain itu, terdapat buyut mengenai tanah Baduy supaya tetap terjaga kesuciannya, sebagai berikut (Sam dkk., 1986: 46):

"teu meunang digaru atawa diwuluku teu meunang digarap dikipar teu meunang katincak kebo keuna ku buyut nahun, buyut karuhun, buyut karang, buyut nabi, buyut para wali" (tidak boleh dibajak dan diweluku tidak boleh digarap dengan cangkul tidak boleh terinjak kerbau terkena pantangan nenek moyang, yaitu pantangan yang sudah sejak lama berurat berakat dari nenek mpoyang, sehingga merupakan pantangan yang tidak bisa dilanggar bagaikan karang, terkena pantangan dari Nabi dan para wali) 
Pemegang mandat pelaksana buyut di atas adalah puun. Sebab itu, terdapat buyut mengenai tindakan puun juga yang terkodifikasi secara internal dalam diri puun, sebagai berikut (Sam dkk., 1986: 48):

"tidak boleh beristeri lebih dari seorang

tidak boleh makan daging

tidak boleh bertemu dengan orang luar sebelum mencapai umur 25 tahun, kalau menjadi puun dalam usia muda

makan harus menggunakan piring kayu, cangkir bambu atau batok kelapa

tidak boleh merokok

tidak boleh bepergian ke luar kecuali dipanggil Pemerintah, itu pun tidak boleh menaiki kendaraan"

Buyut bagi puun tersebut diorientasikan supaya puun tetap terjaga kesuciannya dalam bertugas dan bertanggung jawab melaksanakan buyut bagi umat Sunda Wiwitan.

Dalam praktiknya buyut Sunda Wiwitan tersebut terbagi menjadi dua jenis: buyut adam tunggal dan buyut nahun. Buyut adam tunggal adalah tabu pokok dengan tabu-tabu kecil lainnya yang hanya berlaku bagi masyarakat Baduy Dalam tangtu. Buyut nahun adalah tabu yang didasarkan hal-hal pokok saja yang berlaku bagi masyarakat Baduy Luar penamping dan dangka. Misalnya, pikukuh buyut mengolah tanah pertanian menjadi sawah dan menanam pohon kopi dan cengkeh hanya berlaku bagi masyarakarat Baduy Dalam tangtu, tetapi bagi masyarakat Baduy Luar penamping dan dangka dibolehkan menanam pohon kopi dan cengkeh (Permana, 2006: 39). Pelaksanaan buyut tersebut dikokohkan dengan ritual penyapuan, pembersihan, atau sanksi. Tujuan ritual penyapuan adalah membersihkan sumber kotoran dari batin pelanggar dan lingkungannya. Ada dua sanksi yang harus dijalani. Pertama, disisihkan dari lingkungan hidup sehari-harinya. Kedua, diturunkan status kewargaannya. Selain itu, ada sanksi lain yang sangat berat, sebagai berikut:

“(1) pelanggar buyut langsung ditindak, sedang yang suka-rela harus mengajukan permohonan undur rahayu kepada puun. (2) pelanggar buyut ditetapkan masa pembuangannya, biasanya 40 hari, sedangkan yang suka-rela tidak. (3) pelanggar buyut jika dinilai baik dan ingin kembali ke tempat asalnya akan 'diala' setelah habis masa hukumannya, sedangkan yang suka-rela jika ingin kembali ke tempat semua harus mengajukan permohonan ijin kepada puuni" (Danasasmita, 1984: 101).

Orientasi pikukuh dilaksanakan oleh umat Sunda Wiwitan untuk tiga amalan. Pertama, ngabara-tapa-keun, amalan tapa terhadap inti jagat dan dunia. Tapa bukan melakukan samadi atau tirakat berdiam diri di tempat sunyi, tetapi melakukan "banyak kerja dan sedikit bicara”. Sebab itu, tapa Baduy adalah bekerja di ladang. Berladang 
diamalkan bukan hanya sekadar menanam padi, melainkan juga sebagai amalan ajaran agama. Kedua, ngare-remo-keun, amalan menghormati dengan mengawinkan Nyi Pohaci Sanghyang Asri (Dewi Padi) dengan bumi. Amalan kedua ini merupakan ajaran agama Sunda Wiwitan. Ketiga, amalan mengekalkan pikukuh dengan melaksanakan semua aturan yang ada (Permana, 2006: 40-41).

Pikukuh Sunda Wiwitan di atas dikukuhkan dengan kearifan atau filsafat hidup sehari-hari. Filsafat hidup yang diajarkan di dalam agama Sunda Wiwitan adalah bahwa "kehidupan manusia itu telah ditentukan kedudukannya dan tempatnya masing-masing." Filsafat hidup ini dapat menjelaskan bahwa manusia harus menerima kodratnya masingmasing dan menempati tempat yang sudah ditentukan. Manusia hidup di dunia ini tidak boleh berlebihan dalam mencari kesenangan, cukup menerima yang sudah ada saja. Sebab itu, tujuan hidup bagi umat Sunda Wiwitan adalah kebajikan (goodness) yang dapat dicapai dengan jalan mentaati pikukuh yang sudah dikodratkan dan yang diberikan kepada kita masing-masing. Jika tidak, berarti hidup itu tidak baik yang akan dirasakan sebagai siksaan atau neraka.

Demikian itu menekan bahwa hidup berarti narimakeun kana kadar (menerima yang sudah ditentukan dan jauh dari hawa nafsu). Dengan kata lain, hirup narimakeun berarti hidup menerima apa yang sudah menjadi bagiannya, sehingga membuatnya tidak berani untuk berbuat atau hidup di luar yang ditentukan (Rosmana dkk., 1993: 88-90). Sebab itu, pandangan hidup umat Sunda Wiwitan ini yang dipraktikkan dalam ibadah ritual keagamaan yang diatur dengan pikukuh dan ketaatan pada buyut, menentukan keberhasilan panen padi yang melimpah dan kesejahteraan umat manusia.

\section{Kesimpulan}

Sunda Wiwitan merupakan pencampuran antara Islam dan Hindu yang dianut oleh masyarakat Baduy di Desa Kanekes, Banten Selatan. Meskipun umat Sunda Wiwitan tidak memiliki kitab suci, akan tetapi ajaran-ajarannya terjelma dalam tapa, bekerja sehari-hari di ladang. Pemahaman ajaran-ajaran agama itu langsung dipraktikkan di dalam interaksi umat dengan alamnya. Hal ini yang dikatakan oleh James Frezer bahwa agama Sunda Wiwitan mengekspresikan makna-makna simbolik di dalam relasi-relasi sosialbudaya dan kosmologi alam Baduy. Keimanannya kepada Allah hanya terlihat di dalam pengucapan kalimat syahadat, namun mereka melakukan praktik ritual keagamaan dengan berpedoman pada pikukuh, aturan adat, dan ketaatan kepada buyut, pantangan. Keimanan seperti itu merupakan semangat untuk menjaga hutan, sungai dan gunung 
hidup harmoni. Seperti, tindakan mereka melaksanakan ritual ibadah pe-muja-an di Sasaka Domas, tanah suci Baduy.

Dengan demikian, identitas Sunda Wiwitan adalah agama sinkretis. Religi ini memberikan pandangan hidup kepada umatnya supaya hidup sederhana dan menerima apa adanya, hanya untuk dapat bekerja di ladang, menanam padi, dengan damai dan sejahtera. Pandangan hidup ini mengkonstruksi pribadi-pribadi Baduy yang taat menjaga alam lindung Kanekes. Di samping itu, menciptakan agama ini tetap lestari secara turun temurun dengan penganut yang semakin bertambah.

\section{Daftar Pustaka}

Ahimsa-Putra, Heddy Shri. 2006. Strukturalisme Lévi-Strauss, Mitos dan Karya Sastra. Cetakan Pertama. Yogyakarta: KEPEL Press.

Danasasmita, Saleh dan Anis Djatisunda. 1984. Kehidupan Masyarakat Kanekes. Jakarta: Departemen Pendidikan dan Kebudayaan Direktorat Jenderal Kebudayaan Proyek Penelitian dan Pengkajian Kebudayaan Nusantara (Javanologi).

Dhavamony, Mariasusai. 1995. Fenomenologi Agama (terj.). Yogyakarta: Kanisius.

Djoewisno, MS. 1987. Potret Kehidupan Masyarakat Baduy. Banten: Cipta Pratama Adv.pt.

Ekadjati, Edi S. 1995. Kebudayaan Sunda (Suatu Pendekatan Sejarah). Jakarta: Pustaka Jaya.

Garna, Judistira. 1987. Orang Baduy. Bangi: Universiti Kebangsaan Malaysia.

. 1988a. Perubahan Sosial Budaya Baduy. Dalam Nuhhadi Rangkuti (peny.), Orang Baduy dari Inti Jagat [page 11-12]. Yogyakarta: Bentara Budaya, Kompas, Etnodata Prosindo, Yayasan Budhi Dharma Praseda.

1993a. Masyarakat Baduy di Banten. Dalam Koetjaraningrat (ed.), Masyarakat Terasing di Indonesia [page 120-152]. Jakarta: Departemen Sosial RI, Dewan Nasional Indonesia untuk Kesejahteraan Sosial dan Gramedia.

1993b. Orang Baduy di Jawa: Sebuah Studi Kasus mengenai Adaptasi Suku Asli terhadap Pembangunan. Dalam Lim Teck Ghee dan Alberto G. Gomes (peny.), Suku Asli dan Pembangunan di Asia Tenggara [page 142-160]. Jakarta: Yayasan Obor Indonesia.

Geertz, Clifford. 1973. The Interpretation of Cultures, Selected Essays. London: Hutchinson \& Co (publishers) Ltd. 
Miles, Matthew B. dan A. Micheal Huberman. 1992. Analisis Data Kualitatif (terj.). Jakarta: Penerbit Universitas Indonesia.

Permana, R. Cecep Eka. 2006. Tata Ruang Masyarakat Baduy. Jakarta: Wedatama Widya Sastra.

Rosmana, Tjetjep dkk. 1993. Kompilasi Eksistensi Lembaga Adat di Jawa Barat. Bandung: Departemen Pendidikan dan Kebudayaan Dirjen kebudayaan dan Balai Kajian Sejarah dan Nilai Tradisional.

Sam, A. Suhandi dkk. 1986. Tata Kehidupan Masyarakat Baduy di Propinsi Jawa Barat. Bandung: Departemen Pendidikan dan Kebudayaan Proyek Inventarisasi dan Dokumentasi Kebudayaan Daerah.

Spradley, James P. 2006. Metode Etnografi. Terjemahan. (Edisi ke-2). Yogyakarta: Tiara Wacana.

Sudibjo Z.H. t.t. Babad Tanah Jawi. Jakarta: Departemen Pendidikan dan Kebudayaan. 